\section{Ministry of Health State of Kuwait}

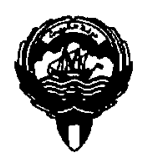

Announces vacant posts for Consultants, specialists in Anaesthesia and Intensive Care to work in its hospitals under the following conditions:

- Medical School graduates (MB.B.Ch).

- Higher professional qualification in anaesthesia and intensive care.

(American Board - Canadian Board - M.D. - British Fellowship - FRCA or equivalent degrees).

- (10) years' experience in anaesthesia and intensive care after higher qualification at least.

- Two scientific research publications in anaesthesia and intensive care in reputable journals.

Submit:

Complete Curriculum Vitae

References and recommendations

To:

Undersecretary

Ministry of Health

P.O. Box 5 - Safat 13001

Kuwait

\section{Clinical Fellowships}

University of Ottawa / Ottawa General Hospital

The Ottawa General Hospital is offering Clinical Fellowships in Anaesthesia, one starting January 1997 and three in July 1997. The Ottawa General is a major teaching hospital of the University of Ottawa. Clinical fellowships include Regional Anaesthesia, Obstetric Anaesthesia and Chronic Pain Management. There is protected time for research. Applicants must be eligible for Canadian certification, American Board eligible, or hold equivalent specialty certification in Anaesthesia from another country. Interested individuals should send a curriculum vitae and three letters of reference to:

\section{Fellowships Cliniques}

\section{Université d'Ottawa / Hôpital Général d'Ottawa}

Le Département d'Anesthésie de l'Hôpital Général d'Ottawa offre 3 fellowships cliniques, l'un débutant en janvier 1997 et 2 autres en juillet 1997. L'Hôpital Général d'Ottawa est un centre enseignant majeur affiliéà l'Université d'Ottawa. Les fellowships sont disponibles en Anesthésie Régionale, Anesthésie Obstétrique et en Traitement de la Douleur Chronique. Il y a une partie du temps dévoué aux projets de recherche. Les candidats doivent être éligibles à obtenir la certification de spécialiste en Anesthésie au Canada ou aux Etats-Unis, ou encore, posséder les qualifications de spécialiste en Anesthésie équivalentes d'un autre pays. Les individus intéressés doivent faire parvenir un curriculum vitae et 3 lettres de référence à l'adresse suivante:

Dr. Dennis Reid

Head, Department of Anaesthesia

Ottawa General Hospital

501 Smyth Road

Ottawa, Ontario K1H 8L6
Fax: (613)737-8189 Tel: (613)737.8187

\section{St. Joseph's Hospital - Comox POSITION AVAILABLE FOR ANAESTHETIST}

St. Joseph's General Hospital, Comox, B.C., located on the scenic east coast of Vancouver island, is seeking a part-time anaesthetist to join four other full-time anaesthetists on staff, commencing in January, 1997.

The hospital is a modern, fully accredited facility with 120 acute care (including $5 \mathrm{ICU}$ ), 15 nursery, and 125 extended care beds. All surgical specialties except neuro, cardiac, and plastics are represented. There is a possibility of further work in ICU and pain management.

The Comox Valley offers numerous attractions including skiing, hiking, golfing, cycling, sailing, and salmon fishing. The climate is mild year around with some of the most beautiful scenery in the Pacific Northwest. The Comox Valley is serviced by $1 / 2$ hour flights to and from Vancouver several times a day, and the ferry to Vancouver is just $1-1 / 2$ hours south.

Those interested should submit curriculum vitae to

$$
\text { Dr. J.F. Keresztesi }
$$

Department of Anaesthesia

St. Joseph's General Hospital

2137 Comox Avenue

Comox, B.C. V9M 1P2

For further information, contact $\mathrm{Dr}$. J. Keresztesi at:

Phone: (604) 339-2242 (Work) or

(604) 339-7290 (Home) Fax: (604) 339-1432

Dr. K. Henderson, Medical Director, at (604) 339-1457.

\section{ISSUES IN ANAESTHESIA \& INTENSIVE CARE}

(A Scientific Meeting celebrating the Bicentenary of the Royal Victoria Hospital)

Belfast, N Ireland

May 22-23. 1997

The meeting will take place in the Waterfront Hall, Belfast. There will be a Scientific Programme on both days of the meeting with a panel of international speakers and topics covering anaesthesia, intensive care and pain.

There will be an Opening Reception on the evening of 21st May and the Conference Dinner will be on Thursday 22nd May.

Accompanying persons are welcome, for whom a separate programme will be available during the course of the Scientific meeting.

For further particulars and registration package, please contact:

Mrs. S. Logan, Department of

Clinical Anaesthesia, Royal Victoria Hospital, Belfast, BT12 6BA Tel \& Fax: +44 232325725 